\title{
The effect of commuter line train's service quality to customer satisfaction and customer loyalty
}

\author{
Putiri Bhuana Katili ${ }^{1}$, Fenna Dewi Setyawati ${ }^{2}$, Nurul Ummi ${ }^{3}$ \\ \{putiri@untirta.ac.id ${ }^{1}$ \} \\ Program of Industrial Engineering, Faculty of Engineering, Universitas Sultan Ageng Tirtayasa, Banten, \\ Indonesia ${ }^{1,2,3}$
}

\begin{abstract}
Jakarta as the capital city of Indonesia has the highest level of mobility. Also, Jakarta is highly dependent on some buffer zones such as Bogor, Depok, Tangerang, Bekasi, and Serpong for economic growth. Effective and efficient transportation is needed for adequate Mobilization of the buffer zone population to Jakarta. The commuter line is the best transportation company for an excellent mobilization. This research was conducted at PT Kereta Commuter Indonesia. The customer loyalty factor of Commuter line KRL is mostly influenced by service quality service and customer satisfaction. The objective of this research is to measure the positive effect of quality service and customer satisfaction on customer loyalty. The method used in this research is structural equation modeling using Lisrel 8.8 with 215 respondents. The data obtained from this research shows that there is positive influence of service quality on customer satisfaction with value 0.50 , service quality influences customer satisfaction with 0.50 value, service quality has the influence on customer loyalty with value 0.10 , and customer satisfaction has the effect on customer loyalty with value 0.66 .
\end{abstract}

Keywords: service quality, satisfaction, loyalty, transportation, structural equation modelling

\section{Introduction}

\subsection{Background}

Public transport plays a vital role in reducing congestion in Indonesia [1], [2], [3]. Congestion can be reduced by an increment of in the number of public transportation users. It majorly occurs in big cities of Indonesia, such as Jakarta, Bandung, Surabaya, Medan, and Denpansar. In Jakarta, it has many disadvantages such as inefficiency in time management and increases in the number of accidents, stress, fuel wastage, and air pollution. Jakarta has successfully played a major role as the capital city as a good business centre in Indonesia. It has the highest level of mobility, and it is highly dependent on buffer zones such as Bogor, Depok, Tangerang, Bekasi, and Serpong. For proper Mobility of the buffer zone population to Jakarta, there is a need for effective and efficient transportation. There are many choices of public transportation that but the commuter line is the choice. This transportation line has many advantages over others and some include fuel-efficiency, it is environmentally friendly, it has its path, cost-effectiveness, mass and punctuality in service delivery [4].

They have a record of yearly increase in the number of customers. They had a total ofPublic transport in Indonesia plays an important role to reduce congestion [1],[2],[3]. Congestion can 
be reduced due to increment of public transportation user. Congestion occurs in big cities of Indonesia, such as Jakarta, Bandung, Surabaya, Medan, and Denpansar. Congestion in Jakarta causes some adverse effects such as inefficient time and increment of accidents, stress, wasted fuel, and air pollution. Jakarta plays role as the capital city, central government and business center in Indonesia. It has highest level of mobility and highly dependent on the buffer zone that is Bogor, Depok, Tangerang, Bekasi and Serpong. Mobility of the buffer zone population to Jakarta needs an effective and efficient transportation. There are many choices of public transportation that meet the needs. The commuter line can be one of the choice. The commuter line has many advantages such as fuel-efficient, environmentally friendly, has its own path, low cost, mass and also faster in time [4].

The passenger of KRL commuter line is increasing every year. The total of KRL passengers of 158.482.102 people in 2013, in 2014 it increased to 208,494,094 people, then in 2015, they got a total of $257,530,195$ persons. In 2016, the total of KRL passengers was $280,588,767$ people, by 2017 it increased to $315,811,848$. On average, the clients on working days amounted to 953,932 , and the highest number of users recorded 1,065,522 passengers per day on 19 June 2017. As a mode of transportation company, the commuter line is operated by PT KCI. This company currently serves 75 stations in all Jabodetabek with a total of $418,5 \mathrm{~km}$ route length [5].

PT Kereta Commuter Indonesia (KCI) is a subsidiary of PT KAI. The Cultural Transformation of PT KAI is part of organizational transformation triggered by the changing demands of the business environment. The major role of PT KCI is managing rail freight services business which is the electric commuter train in Greater Jakarta and surrounding areas as well as concessions in non-passenger business.

According to Fadillah, there are various factors that promote customer loyalty and they include; service quality, customer satisfaction, and price. Furthermore, research was conducted by Kamaruddin, Osman, and Pei [1] using public transport services at Kang Valley as a case study. It was concluded that there is a strong relationship between the environment and customer satisfaction with customer loyalty. According to Gures, Arslan, and Tun [6] with a study case on Turkish Airline, customer loyalty is influenced by customer satisfaction. Therefore, it can be concluded that factors such as service quality, customer satisfaction, and the environment have an influence on customer loyalty.

This research demonstratesBased on research conducted by Fadillah, there are various factors that influence customer loyalty such as service quality, customer satisfaction, and price. In addition, research conducted by Kamaruddin, Osman, and Pei [1] with a study case on public transport services at Kang Valley, concluded that there is an influence between the environment, and customer satisfaction with customer loyalty. In research Gures, Arslan, and Tun [6] with a study case on Turkish Airline, customer loyalty factor influenced customer satisfaction. From previous statement, it can be concluded that factors such as service quality, customer satisfaction, and environment has implication to customer loyalty.

This research conducted in KRL commuter line of PT KCI. This research determine the influence of service quality and customer satisfaction on the customer loyalty of KRL commuter line customer. Service quality is selected at PT KCI because there are still many complaints experienced by customers lay regular feedback on services in KRL. Customer satisfaction is an issue of great importance in PT KCI because it makes customers come back for more. The KRL employees are vested with the responsibility of improving service quality to ensure that the customer needs are met.

There are several methods of determining the relationship between variables such as Structural Equation Modeling (SEM) method and multiple regression. SEM can perform 
parallel testing [7] and estimates on measurement error with its existing facilities [8]. These are some limitations of multiple regression methods. This research used SEM (Structural Equation Modelling) method with the aid of Lisrel 8.80 software.

\subsection{Research purposes}

The research objectives in this study are as follow:

1. To determine the positive impact of the implementation of service quality to commuter line customer satisfaction in the commuter line.

2. To show the positive impact of service quality implementation on the company's customer loyalty .

3. To determine the positive effects of customer satisfaction implementation on customer loyalty in general term

\section{Literature review}

Customer Loyalty has to do with the possibility that customers would repurchase from the same supplier in the future and also perform some recommendations in the promotion of the company's brand [1]. Hapsari [9] defines loyalty as "a solid commitment to return or repair a consistent choice of products/services in the future, causing the same repeated purchases and marketing efforts that will potentially lead to switching behavior. Customer loyalty is the behavior performed by a client to repurchase a product or service even though many competing companies of similar products/services offer the same or alternative product/service [10].

TjiptonoCustomer Loyalty is a combination of possibility that customers would repurchase from the same supplier in the future and give recommendations or engage in promotions [1] Hapsari [9] defines loyalty as "a very strong commitment to return or repair a consistent choice of products / services in the future, causing the same repeated purchases and marketing efforts that potentially lead to switching behavior. Customer loyalty is the behavior performed by a customer to repurchase a product or service even though many competing companies of similar products / services offer the same or alternative product / service [10].

Tjiptono , explains that the word satisfaction is derived from the Latin language: "satis" (means good enough, adequate) and "facio" (do or make) [11]. Customer satisfaction is the level of satisfaction or dissatisfaction as a result of differences between what customers expect from a product/service and what is actually received. Customer satisfaction is a subjective response after evaluating expectations in accordance with reality[12].

Service quality is the customer's evaluation of the actual service execution provided [12]. American Society for Quality Control defined quality is the totality of features and characteristics of a product or service that depends on its ability to satisfy the needs of its users[13].

Service quality is the customer's evaluation of the actual service execution provided [12]. The meaning of quality based on the definition of American Society for Quality Control, quality is the totality of features and characteristics of a product or service that depends on its ability to satisfy the needs [13].

The formulation of hypotheses to be tested in this study are: 
H1: quality service has positive effect on customer satisfaction

$\mathrm{H} 2$ : There is a positive effect of quality service on customer loyalty

H3: There is a positive effect of customer satisfaction positively infuences customer loyalty.

\section{Method}

This research descriptively applied the quantitative approach. The object of research is the commuter line (KRL) customers. Data were obtained through the distribution of questionnaires on KRL customers cross the red line (Bogor-Jakarta Kota). The research result can be accessed in https://osf.io/8fepy/ Open Science Framework [14]. The questionnaire is divided into two sections. The first section includes respondents' demographic data information. The second section consists of 43 statements derived from previous studies that contain three variables and ten dimensions in Figure 1.

On the second section, respondents had to choose one among five options written on the Likert measurement scale. There are 218 questionnaires were distributed directly at Manggarai Station, Bogor Station, Jakarta Kota station and online. From 218 questionnaires, 215 data were obtained for further analysis using SEM (Structural Equation Modeling) method with the aid of the Lisrel 8, 8. The number of samples has met the number of samples recommended amount for the structural equation model which was 150-400 respondents [15].

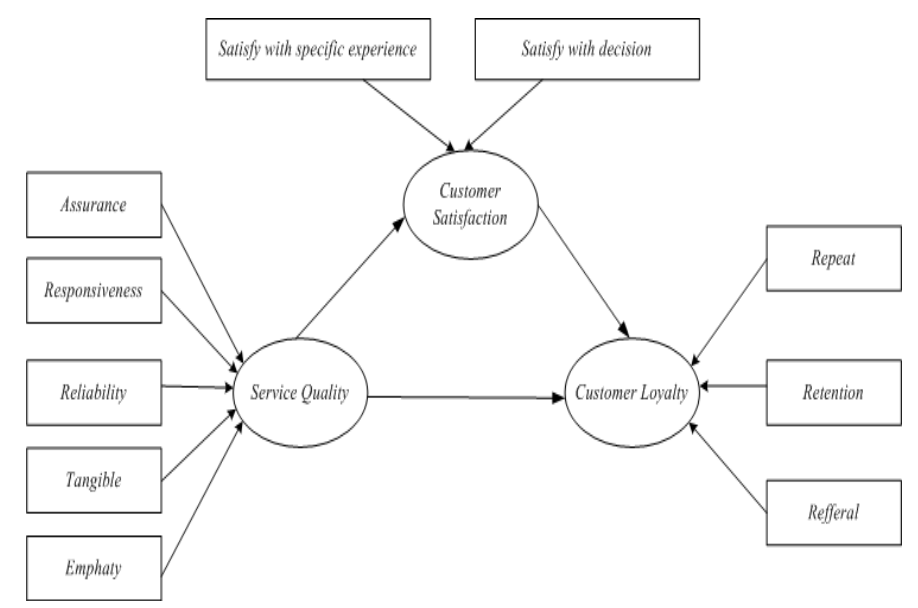

Fig 1. Conceptual Model of Research 


\section{Result and Discussion}

This study was conducted by first testing the questionnaire first. The questionnaire was tested by the instrument test to determine its validity and reliability. The instrument test was conducted with 30 respondents to test the questionnaire. Validity and reliability test are carried out using the SPSS 20 software. Validity indicates the degree to determine which the evidence supports the conclusions drawn from scores derived from the size [16]. The questionnaire is valid if rtable < rcount or rtable is smaller than rarithmetic. Reliability is defined as the overall consistency of the measurement with minimum random error. Too much random error would lower the measurement reliability level. A questionnaire is reliable if Cronbach's Alpha value > 0,60 [8], [15]. After instrument testing, the data was processed by SEM (Structural Equation Modeling) method.

Phase-stage procedure according to Wijanto SEM includes the specifications of a mathematical model of the research model, identification, estimation of measurement models with CFA (Confirmatory Factor Analysis), compatibility test of the overall model (Goodness of Fit), and re-specification [8],[15].

Finally, all relevant results in the measurement model after the previous modification index is shown in Table 1.

Table 1. Results of Analysis and Interpretation of Estimation Parameters for SEM.

\begin{tabular}{llllll}
\hline Hypothesis & Construct & Significant Level & Estimate & P-values & $\begin{array}{l}\text { Significance } \\
\text { (Yes No) }\end{array}$ \\
\hline H1 & $\begin{array}{l}\text { SERVQUAL } \rightarrow \\
\text { SATISFACT }\end{array}$ & 0.05 & 0.50 & 0.11329 & Yes \\
H2 & $\begin{array}{l}\text { SERVQUAL } \rightarrow \\
\text { LOYALTY }\end{array}$ & 0.05 & 0.10 & 0.11329 & No \\
H3 & SATISFACT $\rightarrow$ & & & & \\
& LOYALTY & 0.05 & 0.66 & 0.11329 & Yes \\
\hline
\end{tabular}

\section{Conclusion}

After conducting the research on KRL and performing some data processing, it can be concluded that service quality has a significant influence on customer satisfaction, service quality has a positive and insignificant effect on customer loyalty, and customer satisfaction has a substantial impact on customer loyalty.

\section{References}

[1] R. Kamaruddin, I. Osman, and C. A. C. Pei,.: Public Transport Services in Klang Valley: Customer Expectations and Its Relationship Using SEM, Procedia - Soc. Behav. Sci., vol. 36, pp. 431-438, 2012. 
[2] K. Ambak, K. K. Kasvar, B. D. Daniel, J. Prasetijo, and A. R. Abd Ghani.: Behavioral Intention to Use Public Transport Based on Theory of Planned Behavior, MATEC Web Conf., vol. 47, p. 3008, 2016.

[3] M. Rizan, E. Fadillah, and A. P. Kresnamurti Rivai.: Influence of Service Quality and Fare Toward Customer Satisfaction and Its Impact on Customer Loyalty of Express Taxi in Jakarta, J. Ris. Manaj. Sains Indones. |, vol. 6, no. 2, pp. 618-638, 2015.

[4] A. S. Wibowo.: Analysis of Consumer Satisfaction Against Service Quality Commuter line KRL Bogor-Jakarta, 2013.

[5] Team.: Reprt Occpancy PT KCI, Jakarta, 2017.

[6] N. Gures, S. Arslan, and S. Yucel Tun.: Customer Expectation, Satisfaction and Loyalty Relationship in Turkish Airline Industry, Int. J. Mark. Stud., vol. 6, no. 1, pp. 6674, 2014.

[7] Latan, Structural Equation Modeling Concepts and Application Using the Lisrel 8.8. 2012.

[8] S. H. Wijanto.: Metode Penelitian menggunakan SEM dengan Lisrel 9. 2015.

[9] R. Hapsari, M. D. Clemes, and D. Dean.: The impact of service quality, customer engagement and selected marketing constructs on airline passenger loyalty," Int. J. Qual. Serv. Sci., vol. 9, no. 1, pp. 21-40, 2017.

[10] L. A. Kasiri, K. T. Guan Cheng, M. Sambasivan, and S. M. Sidin,.: Integration of standardization and customization: Impact on service quality, customer satisfaction, and loyalty," J. Retail. Consum. Serv., vol. 35, no. June 2016, pp. 91-97, 2017.

[11] F. Tjiptono.: Service, Quality and Satisfaction. 2016.

[12] J. Minser and V. Webb.: Quantifying the Benefits: Application of Customer Loyalty Modeling in Public Transportation Context, Transp. Res. Rec. J. Transp. Res. Board, vol. 2144, no. 1, pp. 111-120, 2010.

[13] Kotler.: Manajemen Pemasaran. 2009.

[14] K. P. Bhuana.: Data Set, 2019. [Online]. Available: https://osf.io/8fepy/. [Accessed: 06-Jan-2019].

[15] J. F. Hair., W. C. Black, B. J. Babin, and R. E. Anderson.: Multivariate Data Analysis William C. Black Seventh Edition. 2014.

[16] Trihendradi, Easy Steps to Perform Statistical Analysis Using SPSS 19. 2011. 
